\title{
Results on blood cell morphology and differential blood cell counts from seventeen Steller sea lion Eumetopias jubatus pups
}

\author{
Donna H. Bishop ${ }^{1}$, J. Frank Morado ${ }^{2, *}$ \\ ${ }^{1} 145$ Saul Dr., Duson, Louisiana 70529, USA \\ ${ }^{2}$ National Oceanic and Atmospheric Administration, National Marine Fisheries Service, Alaska Fisheries Science Center, \\ 7600 Sand Point Way NE, Seattle, Washington 98115-0070, USA
}

\begin{abstract}
During summer 1991, blood was collected and blood smears were prepared from 17 Steller sea lion Eumetopias jubatus pups. Of the sampled pups 8 were from 3 Southeast Alaska rookeries (Forrester Island, $\mathrm{N}=3$; White Sisters, $\mathrm{N}=4$; Hazy lsland, $\mathrm{N}=1$ ) and 9 were from 2 Gulf of Alaska rookeries (Seal Rocks, $N=5$; Outer Island, $N=4$ ). The total number of white blood cells (WBC) per $\mu$ l was estimated, and differential counts were performed on each smear. Red blood cell (RBC) anomalies were identified and quantified. Only the values from the Hazy Island pup sample appeared remarkable as the levels of banded neutrophils, monocytes, and total WBC counts were greater than 1 standard deviation from the total average values. Poikilocytes and target cells were the most frequently encountered RBC anomalies occurring in all (100\%) and 15 of $17(88 \%)$ sampled pups, respectively. No clear differences were observed between pups from the 2 regions, but total WBC counts from Southeast Alaska pups appeared depressed when compared with Gulf of Alaska values. RBC data indicated that target cells were markedly elevated in Gulf of Alaska pups over Southeast Alaska pups and that poikilocyte levels were higher in Southeast Alaska pups than Gulf of Alaska pups. The results suggest anemia, but given the wide range of reported values from captive, stranded, and wild sea lions, the exact condition of the sampled Steller sea lion pups could not be determined.
\end{abstract}

KEY WORDS: Eumetopias jubatus - Steller sea lion - Differential counts ·Poikilocytes - Target cells . Red blood cells White blood cells

\section{INTRODUCTION}

Recent abundance estimates indicate that a marked decline of the Steller sea lion Eumetopias jubatus population has occurred throughout most of its range (Merrick et al. 1987, Loughlin et al. 1990, 1992, Sease et al. 1993). The declines prompted the listing of the Steller sea lion as threatened under the U.S. Endangered Species Act and the development and execution of a Recovery Plan (National Marine Fisheries Service 1992). Because lethal methods for collecting Steller sea lions are not desirable, a need exists for non-lethal and preferably repetitive methods that can

\footnotetext{
- Addressee for correspondence;

E-mail:moradof@race.afsc.noaa.gov
}

provide information on the health status of adults, juveniles, and pups.

Hematology is a valuable tool in determining the health status of wild and domestic (Latimer \& Rakich 1989) animals although the usefulness of reported marine mammal values (Fowler 1986, Bossart \& Dierauf 1990 ) is less clear. The reasons for the shortcomings of many marine mammal hematological studies include: (1) small sample sizes (Ronald \& Kay 1982); (2) the possible existence of subclinical disease (Bossart \& Dierauf 1990); (3) insufficient case history knowledge, especially of wild animals; and (4) failure to standardize results. This study was initiated to begin gathering baseline data on the morphology and quantification of both red (RBC) and white (WBC) blood cells from wild Steller sea lion Eumetopias jubatus pups. 


\section{METHODS}

Blood samples from 17 Steller sea lion pups were collected in the field during summer 1991 for morphological examination and quantification of both RBCs and WBCs. Sampled pups were between 1 and 4 wk of age. Of the sampled pups 8 were from 3 Southeast Alaska rookeries (Forrester Island, $N=3$; White Sisters, $\mathrm{N}=4$; Hazy Island, $\mathrm{N}=1$ ), 5 were from Seal Rocks in the eastern Gulf of Alaska, and 4 were from Outer Island in the central Gulf of Alaska (Fig. 1).

Blood was withdrawn from either the jugular vein or the extradural intravertebral vein with a syringe that contained EDTA as anticoagulant. Smears were manually prepared within $6 \mathrm{~h}$ post-withdrawal after gentle mixing; the smears were allowed to air dry and were then transported to the laboratory for staining with a Hemacolor kit 6 to $8 \mathrm{wk}$ after collection. Blood smears were read blind and in triplicate Leukocyte differential counts were determined after 100 WBCs were identified and counted from each area under $400 \times$ magnification using the Battlement method (Koepke 1984). WBC cell density was also estimated from each blood smear (Fraser \& Mays 1986). RBC morphology and prevalences were determined at $400 \times$ magnification after 200 cells per observation were counted. Group and sample means and standard deviations were determined for each blood cell type (Tables $1 \& 2$ ).

\section{RESULTS}

\section{Leukocytes}

Leukocyte morphology was essentially unremarkable as several types (e.g. segmented neutrophils, banded neutrophils, monocytes, lymphocytes, eosinophils), except for basophils, were routinely encountered in examined blood smears. The percentage composition of each cell type and their respective standard deviations (SD) are shown in Table 1 . The majority of WBC determinations were within $1 \mathrm{SD}$ of the calculated mean values for pups from all areas combined; the exception being the Hazy Island pup which possessed increased levels of banded neutrophils $(6.0 \%)$, monocytes $(18.7 \%)$, and total WBC counts (11333 cells $\mu l^{-1}$ ) that were greater than 1 SD away from the total average values. The leukograms of the 2 geographic areas (Table 1; Southeast Alaska and Gulf of Alaska) did not differ markedly.

\section{Erythrocytes}

Nucleated erythrocytes, polychromatic cells, poikilocytes, leptocytes or target cells, Howell-Jolly bodies, spherocytes, and stomatocytes were routinely encountered in sampled pups (Table 2). Because several smears were not uniformly spread, cell clumping or rouleaux formation was not considered a viable obser-

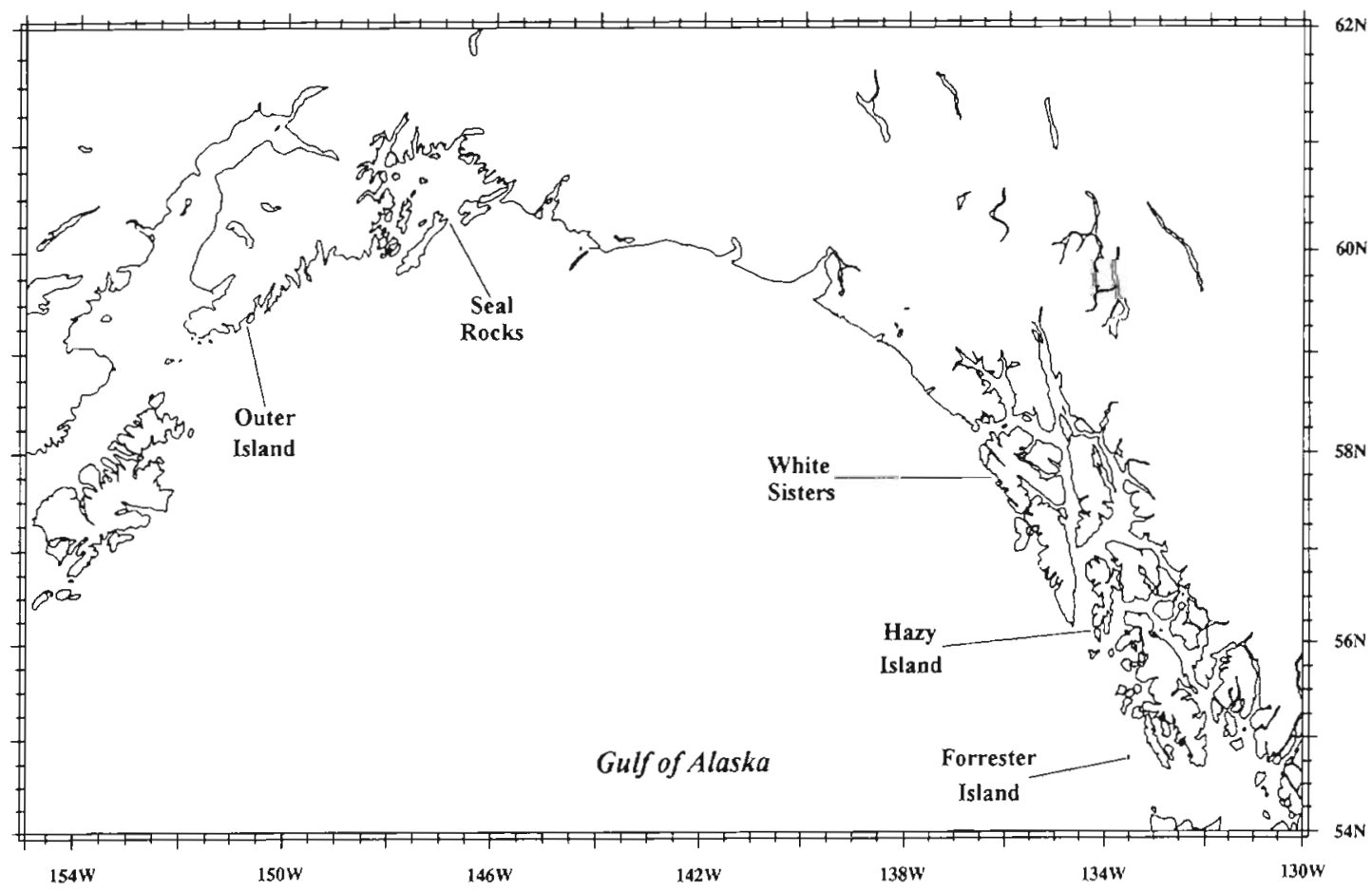

Fig. 1. Sample site locations 
Table 1. Eumetopias jubatus. Differential and total white blood cell (WBC) counts from Steller sea lion pups. Data reported as means $\pm 1 \mathrm{SD}$. All values reported as percentages except for total WBCs, which are reported as cells $\mu \mathrm{l}^{-1} \mathrm{GOA}$ : Gulf of Alaska; SEA: Southeast Alaska

\begin{tabular}{|lcccccccc|}
\hline & $\begin{array}{c}\text { White Sisters } \\
(\mathrm{N}=4)\end{array}$ & $\begin{array}{c}\text { Hazy Island } \\
(\mathrm{N}=1)\end{array}$ & $\begin{array}{c}\text { Forrester Island } \\
(\mathrm{N}=3)\end{array}$ & $\begin{array}{c}\text { Outer Island } \\
(\mathrm{N}=4)\end{array}$ & $\begin{array}{c}\text { Seal Rocks } \\
(\mathrm{N}=5)\end{array}$ & $\begin{array}{c}\text { SEA } \\
(\mathrm{N}=8)\end{array}$ & $\begin{array}{c}\text { GOA } \\
(\mathrm{N}=9)\end{array}$ & $\begin{array}{c}\text { All } \\
(\mathrm{N}=17)\end{array}$ \\
\hline $\begin{array}{l}\text { Neutrophils } \\
\text { Banded }\end{array}$ & $66.0 \pm 6.7$ & $62.7 \pm 5.8$ & $66.0 \pm 3.2$ & $68.6 \pm 8.3$ & $70.3 \pm 6.2$ & $65.6 \pm 5.4$ & $69.5 \pm 7.1$ & $67.7 \pm 6.6$ \\
neutrophils & $1.1 \pm 1.4$ & $6.0 \pm 2.7$ & $2.1 \pm 1.4$ & $2.1 \pm 1.2$ & $2.5 \pm 1.6$ & $2.1 \pm 2.2$ & $2.3 \pm 1.4$ & $2.2 \pm 1.8$ \\
Monocytes & $8.3 \pm 2.6$ & $18.7 \pm 4.6$ & $11.7 \pm 4.4$ & $13.1 \pm 6.0$ & $11.2 \pm 3.4$ & $10.9 \pm 4.8$ & $12.0 \pm 4.7$ & $11.5 \pm 4.8$ \\
Lymphocytes & $18.3 \pm 5.1$ & $9.7 \pm 1.2$ & $18.2 \pm 4.7$ & $13.4 \pm 4.0$ & $13.1 \pm 6.3$ & $17.2 \pm 5.3$ & $13.2 \pm 5.3$ & $15.1 \pm 5.6$ \\
Eosinophils & $6.2 \pm 3.1$ & $3.0 \pm 2.6$ & $2.0 \pm 1.0$ & $2.8 \pm 2.0$ & $2.9 \pm 2.7$ & $4.2 \pm 3.1$ & $2.8 \pm 2.4$ & $3.5 \pm 2.8$ \\
Total WBCs & $7833 \pm 1337$ & $11333 \pm 1155$ & $7111 \pm 1054$ & $9000 \pm 1348$ & $9333 \pm 1633$ & $8000 \pm 1769$ & $9185 \pm 1495$ & $8627 \pm 1720$ \\
\hline
\end{tabular}

vation even though it was frequently encountered in pup blood films. Poikilocytosis and target cells were the most frequently observed anomalies in the sampled Steller sea lion pups. Poikilocytosis was evident in all 17 sampled pups $(100 \%)$ whereas target cells were observed in 15 of 17 pups (88\%).

$\mathrm{RBC}$ morphology was quantified because the presence of erythrocyte anomalies reveals much about the health status of feral and wild animals (Coles 1967, Schalm et al. 1975), but no clear correlations between $\mathrm{RBC}$ anomalies and marine mammal health deficiencies have been established. Sea lion pups sampled from Seal Rocks had the highest levels of both target cells $(27.5 \% ;>1 \mathrm{SD})$ and stomatocytes $(0.5 \%)$ and the lowest values of both normal $\operatorname{RBCs}(65.7 \%)$ and poikilocytes $(5.5 \%)$. Forrest Island had the highest level of poikilocytes $(20.5 \%)$ but the lowest prevalence of target cells $(0.95 \%)$. Polychromatic cells, HowellJolly bodies, spherocytes, and stomatocytes were observed at levels of less than $1 \%$ of total RBCs at each rookery (Table 2). Spherocytes were detected only in samples from Seal Rocks. Nucleated RBCs were observed in the majority of blood smears but were not present at measurable levels.

\section{Regional comparisons}

Because of the small sample sizes, it is difficult to draw clear conclusions on the health condition of the sampled pups. However, recent population abundance trends (Sease et al. 1993) imply that the data may be grouped by region for analysis (e.g. Southeast Alaska and Gulf of Alaska). Grouping of the data in this manner suggests that regional differences are not marked for differential and total WBC values even though total WBC counts in Southeast Alaska pups appear depressed when compared with Gulf of Alaska WBC values (Table 1). In a similar fashion, the erythrocyte data suggest that no marked differences exist between pups of the 2 geographic regions, except for target cell values which are markedly elevated in Gulf of Alaska pups (Table 2). Less remarkable are the elevated normal and poikilocyte values of Southeast Alaska pups over the respective Gulf of Alaska values.

\section{DISCUSSION}

Hematological analyses of marine mammals are presented with obvious limitations that likely affect the

Table 2. Eumetopias jubatus. Red blood cell (RBC) morphology and counts from Steller sea lion pups. Data reported as means $\pm 1 \mathrm{SD}$. All values reported as percentages. GOA: Gulf of Alaska; SEA: Southeast Alaska

\begin{tabular}{|lcccccccc|}
\hline & $\begin{array}{c}\text { White Sisters } \\
(\mathrm{N}=4)\end{array}$ & $\begin{array}{c}\text { Hazy Island } \\
(\mathrm{N}=1)\end{array}$ & $\begin{array}{c}\text { Forrester Island } \\
(\mathrm{N}=3)\end{array}$ & $\begin{array}{c}\text { Outer Island } \\
(\mathrm{N}=4)\end{array}$ & $\begin{array}{c}\text { Seal Rocks } \\
(\mathrm{N}=5)\end{array}$ & $\begin{array}{c}\text { SEA } \\
(\mathrm{N}=8)\end{array}$ & $\begin{array}{c}\text { GOA } \\
(\mathrm{N}=9)\end{array}$ & $\begin{array}{c}\text { All } \\
(\mathrm{N}=17)\end{array}$ \\
\hline Normal RBCs & $87.2 \pm 5.7$ & $81.5 \pm 7.8$ & $77.9 \pm 6.9$ & $78.5 \pm 9.9$ & $65.7 \pm 12.0$ & $83.0 \pm 7.5$ & $71.4 \pm 12.7$ & $76.9 \pm 12.0$ \\
Poikilocytes & $6.7 \pm 3.9$ & $10.3 \pm 4.0$ & $20.5 \pm 7.0$ & $10.3 \pm 5.4$ & $5.5 \pm 5.1$ & $12.3 \pm 8.3$ & $7.6 \pm 5.7$ & $9.8 \pm 7.4$ \\
Target cells & $6.1 \pm 5.2$ & $7.5 \pm 4.5$ & $0.9 \pm 1.2$ & $11.0 \pm 8.7$ & $27.5 \pm 15.2$ & $4.3 \pm 4.7$ & $20.2 \pm 15.1$ & $12.7 \pm 13.9$ \\
Polychromasia & $0.1 \pm 0.2$ & $0.7 \pm 0.3$ & $0.4 \pm 0.6$ & $0.1 \pm 0.2$ & $0.7 \pm 0.6$ & $0.3 \pm 0.5$ & $0.4 \pm 0.6$ & $0.4 \pm 0.5$ \\
Howell-Jolly & 0.0 & 0.0 & $0.2 \pm 0.2$ & $0.1 \pm 0.3$ & $0.1 \pm 0.3$ & $0.1 \pm 0.2$ & $0.1 \pm 0.3$ & $0.1 \pm 0.2$ \\
bodies & 0.0 & 0.0 & 0.0 & 0.0 & $0.0 \pm 0.1$ & 0.0 & $0.0 \pm 0.1$ & 0.0 \\
Spherocytes & $0.0 \pm 0.1$ & 0.0 & 0.0 & $0.0 \pm 0.1$ & $0.5 \pm 0.7$ & $0.0 \pm 0.1$ & $0.3 \pm 0.6$ & $0.2 \pm 0.4$ \\
Stomatocytes & & & & & & & & \\
\hline
\end{tabular}


results. Observation, capture, and collection of samples from marine mammals present serious logistical problems because sampling sites are typically remote, exposed to weather and are without adequate facilities for proper sample collection and storage. The case history of the majority of wild marine mammals is unknown. Even for apparently healthy animals the effects of starvation, parasitism, sub-clinical disease, and breeding season are unknown. Beached marine mammals are clearly stressed and, in this study, the last feeding period of sampled pups was unknown. For captured animals, the effects of long-term containment and maintenance of animals under crowded conditions, and the administration of antibiotics, are unknown. It is thus not surprising that the reported hematological data for marine mammals (Hubbard 1968, Fowler 1986, Bossart \& Dierauf 1990) possess wide RBC and WBC parameter ranges. We elected to present our results as means with respective standard deviations because it is our opinion that data tendered in this manner permits a more objective comparison than is possible by reporting value ranges (Bossart \& Dierauf 1990).

This study encountered additional technical problems that likely affected the results. A lapse between sample collection and staining of Steller sea lion pup blood films could not be avoided, and the delay likely affected cell distribution and morphology. Considerable variation in leukocyte distribution, especially of monocytes, is common in manually prepared smears (Stiene-Martin 1980) and may be more pronounced in field preparations. Anticoagulants and prolonged storage are also known to affect blood cell morphology and quantification (Geraci \& Medway 1973, Geraci \& Engelhardt 1974, Schalm et al. 1975).

\section{Differential data}

The present WBC differential data were compared with California sea lion reference (Fowler 1986, Bossart \& Dierauf 1990) and stranded Steller sea lion pup values (Hubbard 1968) because no data exist for adult Steller sea lions. Comparison with California sea lion data is supported by the suggestion that similarities in hematologic values exist among various marine mammal species (Needham et al. 1980, Williams \& Pulley 1983). Indeed, the WBC data from stranded Steller sea lion pups (Hubbard 1968) compare favorably with California sea lion values (Fowler 1986), but the significance of this similarity is not clear because of the wide range in differential counts. Despite this uncertainty, comparison of the present data (Table 1) with the stranded Steller sea lion pup (Hubbard 1968) and California sea lion
(Fowler 1986) values suggests that the sampled, wild Steller sea lion pups possessed monocytosis and depressed levels of banded neutrophils and lymphocytes. In contrast, all WBC pup determinations from this study fell within the limits of the reference values recently reported for adult California sea lions (Bossart \& Dierauf 1990).

In general, the Steller sea lion pup leukograms (Table 1) suggested a slight neutrophilia, monocytosis, and lymphopenia, but an apparent normal leukocyte count $\left(8627\right.$ cells $\left.\mu^{-1}\right)$. This WBC profile resembles a partial, classical corticosteroid stress response of domestic animals (Duncan \& Prasse 1986), but infections (Dierauf et al. 1986, Bossart \& Dierauf 1990), inflammation (Latimer \& Rakich 1989), and certain physiological responses (e.g. fear, excitement, restraint; Medway \& Geraci 1964, Hubbard 1968, Geraci \& Smith 1975, Latimer \& Rakich 1989) are capable of presenting a similar leukocyte profile.

The onset of physiological neutrophilia, monocytosis, and lymphocytosis is rapid and most common in young domestic animals in response to fear, excitement, and strenuous exercise such as that which may occur prior to restraint and venipuncture (Latimer \& Rakich 1989). These conditions also induce a similar hematological profile in young wild animals. Blood from 6 young grey seals possessed high mean monocyte profiles similar to those found in the present study (Greenwood et al. 1971). Even though the average time between capture and venipuncture was about $1 \mathrm{~min}$, handling stress was believed to be the causative factor. Because the mean time from herding to venipuncture was $15 \mathrm{~min}$, handling stress probably influenced the data in the present study. Abandonment of nursing pups while the mother forages for food is another plausible stressor, particularly if extended feeding periods are required.

Although physiological stress likely affected the Steller sea lion pups, the presumptive evidence suggests that many factors contribute to a hematological profile. Differences in total WBC counts and differential counts between adults and neonates have been documented in many species. Total WBC counts are highest in young dogs and gradually decrease with age as do lymphocytes and eosinophils, but monocytes increase slightly with age (Schalm et al. 1975). Sex variations in WBC counts have been documented in goats (Holman \& Dew 1966) and other species (Schalm et al. 1975). Season and reproductive states are also known to alter WBC counts (Holman \& Dew 1966, Schalm et al. 1975). The most obvious obstacle to correlating WBC determinations to the health status of marine mammals is that, despite our best efforts, the true health condition of live, sampled marine mammals is unknown. 


\section{Erythrocyte data}

Many studies have been done on marine mammal $\mathrm{RBC}$ indices, but quantification of RBC morphological variants is not routine. Previous studies have typically concentrated only on reporting observed RBC anomalies; few studies have attempted to determine the contribution of RBC anomalies to erythrograms. When conducted, these studies show that the abundance of polychromatic cells, poikilocytes, anisocytes, and Howell-Jolly bodies varies with age and species (Holman \& Dew 1964, 1966, Schalm et al. 1975). Thus, the presence and abundance of RBC variants could provide important information on the health status of both wild and domestic animals.

Poikilocytes have traditionally been used as an indicator of a pathological condition. However, their numbers may decline or disappear in adulthood (Holman \& Dew 1964). The apparent fragile nature of marine mammal RBCs and their relatively large volumes likely makes them more susceptible to distortion and possible poikilocytosis but this theory needs confirmation.

Target cells have been reported in several conditions, but their nature also remains idiopathic. Target cells may be artifact (Coles 1967) but are often associated with sickle cell anemia, Mediterranean (Cooley's) anemia, other anemias, liver disease, and with splenectomized animals (Krumbhaar 1932, Haden \& Evans 1937, Dameshek 1940, Bohrod 1941, Smith 1943, Valentine \& Neel 1944). In other studies, small numbers of target cells have been reported in physiologically normal dogs and muskrats (Lord et al. 1954). Because target cells have not been documented in other marine mammal hematological profiles, their significance in this study is unknown even though they constituted a major RBC component, especially in Seal Rocks pups.

In general, the sampled sea lion pups presented RBC and $\mathrm{WBC}$ profiles that suggest stress. In particular, an anemic state is indicated because of the presence of several RBC variants, but other RBC indices such as packed cell volumes, hemoglobin, and RBC counts are required for confirmation. The results of this study were likely influenced by logistical problems, but it is hoped that future attempts to record and quantify WBC and RBC anomalies will gain added importance. In particular, it is hoped that efforts will be made to standardize blood sample analyses and to expand the database on normal and pathological RBC and WBC parameters for wild marine mammals. Furthermore, repetitive sampling of individuals would go far toward providing on understanding of normal hematological trends and an assessment of the health of wild marine mammal populations.
Acknowledgements. The authors thank $\mathrm{Mr}$ Don Caulkins (Alaska Dept of Fish \& Game, Anchorage, AK) and Mr Richard Merrick (National Marine Mammal Laboratory, Seattle, WA) for their efforts in sample collection. We further thank Mr Richard Merrick and Dr Micheal Castellini (Institute of Marine Sclence, Univ. of Alaska, Fairbanks, AK) for their critical reviews and helpful suggestions on an earlier version of the manuscript.

\section{LITERATURE CITED}

Bohrod MG (1941) The significance of target cells in anemia. Am J med Sci 202:869-874

Bossart GD. Dierauf LA (1990) Marine mammal clinical laboratory medicine. Chap 1 In: Dierauf LA (ed) CRC handbook of marine mammal medicine: health, disease and rehabilitation. CRC Press, Inc, Boca Raton, Florida, p 1-52

Coles EH (1967) Veterinary clinical pathology. WB Saunders Co, Philadelphia

Dameshek W (1940) Target cell anemia. Anerythroblastic type of Cooley's erythroblastic anemia. Am J med Sci 200: $445-454$

Dierauf LA, Dougherty SA, Lowenstine LJ (1986) Survival versus nonsurvival determinants for neonatal harbor seals. J Am vet med Ass 189:1024-1028

Duncan JR, Prasse KW (1986) Veterinary laboratory medicine, 2nd edn. lowa State University Press, Ames

Fowler ME (1986) Zoo and wild animal medicine, 2nd edn. WB Saunders Co, Philadelphia

Fraser CM, Mays A (1986) The Merck veterinary manual. Merck \& Co, Inc, New Jersey

Geraci JR, Engelhardt FR (1974) The effects of storage time, temperature, and anticoagulants on harp seal Phoca groenlandica, hemograms: a simulated field study. Physiol Zool 47:22-28

Geraci JR, Medway W (1973) Simulated field blood studies in the bottle-nose dolphin, Tursiops truncatus. 2. Effects of stress on some hematological and plasma chemical parameters. J Wildl Dis 9:29-33

Geraci JR, Smith TG (1975) Functional hematology of ringed seals (Phoca hispida) in the Canadian Arctic. J Fish Res Bd Can 32:2559-2564

Greenwood AG, Ridgway SH, Harrison RJ (1971) Blood values in young gray seals. J Am vet med Ass 159: $571-574$

Haden RL, Evans FD (1937) Sickle cell anemia in the white race. Arch intern Med 60:133-142

Holman HH, Dew SM (1964) The blood picture of the goat. II. Changes in erythrocytic shape, size and number associated with age. Res vet Sci 5:274-285

Holman HH, Dew SM (1966) The blood picture of the goat. V. Variations due to season, sex and reproduction. Res vet Sci $7: 276-286$

Hubbard RC (1968) Husbandry and laboratory care of pinnipeds. In: Harrison RJ, Hubbard RC, Peterson RS, Rice CE, Schasterman RJ (eds) The behavior and physiology of pinnipeds. Meridith Corp, New York, p 299-358

Koepke JA (1984) Laboratory hematology, Vol 2. Churchill Livingstone, New York

Krumbhaar EB (1932) The changes produced in the blood picture by removal of the normal mammalian spleen. Am J med Sci 184:215-228

Latimer KS, Rakich PM (1989) Clinical pathology, Part 1, Clinical interpretation of leukocyte responses. Vet Clin $N$ Am Small Anim Pract 19:637-668 
Lord GH, Todd AC, Kabat C (1954) The blood picture of muskrats under pentobarbitol sodium. Am J vet Res January: $79-81$

Loughlin TR, Perlov AS, Vladimirov VV (1990) Survey of northern sea lions (Eumetopias jubatus) in the Gulf of Alaska and Aleutian Islands during June 1989. US Dept Comm NOAA Tech Memo NMFS F/NWC-176

Loughlin TR, Perlov AS, Vladimirov VV (1992) Range-wide survey and estimated of total number of Steller sea lions in 1989. Mar mammal Sci 8:220-239

Medway W, Geraci JR (1964) Hematology of the bottlenose dolphin (Tursiops truncatus). Am J Physiol 207; $1367-1370$

Merrick RL, Loughlin TR, Calkins DG (1987) Decline in abundance of the northern sea lion, Eumetopias jubatus, in Alaska, 1956-1986. Fish Bull US 85:351-365

National Marine Fisheries Service (1992) Recovery plan for the Steller sea lion (Eumetopias jubatus). Prepared by the Steller Sea Lion Recovery Team for the National Marine Fisheries Service, Silver Spring, MD

Needham DJ, Cargill CF, Sheriff D (1980) Haematology of

Responsible Subject Editor: M. D. Dailey, Gunnison, Colorado, USA the Australian sea lion, Neophoca cinerea. J Wildl Dis 16 $103-107$

Ronald K, Kay J (1982) Haematology and plasma chemistry of captive Baikal seals, Pusa sibrica. Aquat Mamm 9:83-94

Schalm OW, Jain NC, Carroll FJ (1975) Veterinary hematology, 3rd edn. Lea \& Febiger, Philadelphia

Sease JL, Lewis JP, McAllister DC, Merrick RL, Mello SM (1993) Aerial and ship-based surveys of Steller sea lions (Eumetopias jubatus) in Southeast Alaska, the Gulf of Alaska, and Aleutian Islands during June and July 1992. US Dept Comm NOAA Tech Memo NMFS-AFSC-1

Smith CH (1943) Familial blood studies in cases of Mediterranean (Cooley's) anemia. Am J Dis Child 65:681-701

Stiene-Martin EA (1980) Cases for poor leukocyte distribution in mammalian spreader-slide blood films. Am J med Technol 46:624-632

Valentine WN, Neel JV (1944) Hematologic and genetic study of transmission of thalassemia. Arch intern Med 74: 185-196

Williams TD, Pulley LT (1983) Hematology and blood chemistry in the sea otter (Enhydra lutris). J Wildl Dis 19:44-47

Manuscript first received: November 17, 1994

Revised version accepted: June 26, 1995 